\title{
The System of Procedural Groundings to Stay Criminal Procedure in Legislation of the Russian Federation
}

\author{
Igor Olegovich Antonov ${ }^{1}$ \\ Andrey Yurievich Verin ${ }^{1}$ \\ Marina Evgenievna Klyukova ${ }^{1}$ \\ Shagieva Rozalina Vasilievna ${ }^{2}$ \\ ${ }^{1}$ Kazan Federal University, Kazan, Russia \\ ${ }^{2}$ State University of Management, Moscow, Russia
}

Doi: 10.36941/ajis-2019-0049

\begin{abstract}
The optimization of individual institutes of criminal procedure legislation contributes to the improvement of domestic criminal proceedings as a whole. One of the most important activities of the legislative bodies in this area is the further rationalization of the criminal case at each stage of the criminal process in accordance with the Russian legislation on the appointment of criminal proceedings. To date, this kind of optimization is impossible without an analysis of established practice and the development on its basis of proposals to improve the institution of suspension of criminal proceedings. In turn, the key place in this legal institution is occupied by the system of procedural grounds for the suspension of criminal proceedings. A balanced, well-thought-out and scientifically justified activity of legislative bodies in this area predetermines the reduction of the risks of reducing the level of protection of the rights and legitimate interests of participants in criminal proceedings. In addition, qualitatively new approaches to solving this problem, improvement of existing and introduction of new procedures in the mechanism of implementation of the Institute of suspension of criminal proceedings can change in a positive way the investigative and judicial practice, minimizing the possibility of artificial (unreasonable) delay of criminal proceedings and adoption of a final decision on it.
\end{abstract}

Keywords: Criminal Proceedings, Ground, Suspension of Proceedings, Party to the Process, Criminal Case, System of Grounds, Procedural Decision

\section{Introduction}

The basis for any procedural decision in criminal proceedings is evidence that establishes the existence of certain circumstances. In order to make a decision to suspend the criminal proceedings, the interrogating officer, investigator, and judge must also make sure that there is sufficient evidence to confirm the existence of objectively temporary obstacles to legal proceedings and there are no conditions that do not allow it to be accepted. The problem of developing a system of grounds for suspension of criminal proceedings, its optimality and sufficiency for making an appropriate decision to this day remains under discussion, because and under the current Code of Criminal Procedure of the Russian Federation has not found its unambiguous solution.

\section{Methods}

The methodological basis of our study was, first of all, the fundamental dialectic method of cognition of social and legal phenomena in the field under consideration, analysis methods, as well as 
system-structural and logical-legal methods. During the study, statistical and comparative legal methods were used, which made it possible to identify the prevalence of the application of the rules governing the suspension of criminal proceedings in legal proceedings.

The key to the study was a method of analyzing judicial investigative and prosecutorial and supervisory practice regarding the suspension of criminal proceedings. Thus, according to the data of the Judicial Department under the Supreme Court of the Russian Federation for 2018, out of 88,701 pending criminal cases, 9,161 criminal cases were suspended, of which 7,792 criminal cases were connected with the search; in connection with a serious illness - 749 criminal cases (Forensic statistics for 2018).

One of the means of studying legal phenomena is considered to be the comparative legal method, since the need to analyze foreign experience in the regulation and application of the institution in question remains relevant for its use in Russia, which predetermined our interest in a wide range of foreign studies in this area. Among them are the works of such scientists as: A. L-T Choo (Choo, 2008), J. Harris (Harris, 2005), H. McDermott (McDermott, 2016), J. McLachlan (McLachlan, 1990), K. Roach (Roach, 1997), J.R. Spencer (Spencer, 2014).

\section{Results and Discussion}

In the literature, the suspension of criminal proceedings is reasonably associated with the onset of circumstances that impede further criminal proceedings in the usual manner (Ibragimova, 2012). The system of grounds for suspension of proceedings in a criminal case in the legislation of Russia includes two subsystems - grounds for suspension of proceedings at the preliminary investigation stage and grounds for suspension of proceedings at judicial stages.

The system of grounds for suspending the proceedings at the preliminary investigation stage is presented as follows: 1) the person to be brought in as an accused has not been established; 2) the accused fled the investigation or his whereabouts have not been established for other reasons; 3 ) the location of the accused is known, but there is no real possibility of his participation in the criminal case; 4) a temporary serious illness of the accused, certified by a medical certificate, impedes his participation in the proceedings.

The position of the legislative bodies, according to which it is possible to suspend criminal proceedings at the preliminary investigation stage due to the temporary absence of not only the accused, but also the suspect in the process, since both are the objects of criminal prosecution, equally entitled to protection, the temporary inability to participate in the process of which prevents the proceedings, should be commended.

The Criminal Procedure Code of the Russian Federation found a new legislative basis for the suspension of criminal proceedings - the whereabouts of the suspect or the accused is known, but there is no real possibility of their participation in the criminal case (Clause 3 of Part 1 of Art. 208 Code of Criminal Procedure). But the legislative bodies do not explain what situations should be regarded as the lack of a real possibility of participation of the accused in a criminal case. This uncertainty of the criminal procedure law causes difficulties in law enforcement practice and has led to a variety of opinions on this issue in the literature (Klyukova, 1990).

The analysis of the legislation of the CIS countries regulating the considered basis of suspension of criminal proceedings shows that the legislative bodies of these countries define its content differently. In some cases, it is limited to a specific list of circumstances objectively preventing the accused from participating in the case (Code of Criminal Procedure of the Republic of Kazakhstan, Art. 45). In others, he connects the suspension on this basis with a non-exhaustive list of objective obstacles that exclude the real possibility of the accused participating in the criminal case (Code of Criminal Procedure of the Republic of Belarus, clause 3, part 1, Art. 246). Such an approach when formulating the grounds under consideration seems more preferable in view of the variety of circumstances that may temporarily prevent the accused from participating in the proceedings due to either his prolonged physical absence or the presence of procedural obstacles. In this regard, it seems necessary to supplement Art. 5 of the Code of Criminal Procedure of the Russian Federation with a definition disclosing the content of such a thing as "the absence of a real possibility for a suspect or accused to participate in a criminal case". 
The basis for the suspension of criminal proceedings has changed due to illness of the suspect or accused. In formulating this ground, the legislative bodies do not distinguish between the illness of the suspect or the accused, which may lead to a decision to suspend criminal proceedings, and mental or other serious, but only a temporary serious illness, certified by a medical report. Given that in accordance with Art. 196 of the Code of Criminal Procedure of the Russian Federation, both the mental and physical condition of the suspect, the accused, when there is doubt about his sanity or ability to independently protect his rights and legitimate interests in criminal proceedings, must be certified by a forensic report, then this is the procedure for confirming the presence of one or another disease should be provided for by criminal procedure law. At the same time, the problem of developing and legislatively fixing clear criteria for the disease, which should determine the decision to suspend criminal proceedings, remains relevant.

The range of circumstances included in the system of grounds for suspending criminal proceedings in the judicial stages of the process is somewhat different than in the preliminary investigation stage.

According to the Article 238 of the Code of Criminal Procedure of the Russian Federation, suspension of a criminal case in preparation for a court hearing, which is carried out in this case in the form of a preliminary hearing, is possible: 1) if the accused has disappeared and his place of residence is unknown; 2) in case of a serious illness of the accused, if it is confirmed by a medical report; 3 ) if the court sends a request to the Constitutional Court of the Russian Federation or the Constitutional Court of the Russian Federation accepts a complaint regarding the compliance of the law applied or to be applied in this criminal case with the Constitution of the Russian Federation; 4) in the case where the whereabouts of the accused is known, but there is no real possibility of his participation in the trial.

At the same time, the legislative bodies introduced an addition that paragraphs 1 and 4 of part 1 of Article. 238 of the Code of Criminal Procedure of the Russian Federation are not applied if there is a request from one of the parties to conduct in exceptional cases criminal proceedings on serious and especially serious crimes in the absence of a defendant who is outside the territory of Russia and (or) avoids appearing in court if this person It was not brought to justice in the territory of a foreign state in this criminal case.

In addition, the legislature provides for the possibility of a preliminary hearing in the absence of the accused at his request. Therefore, Art. 238 of the Code of Criminal Procedure of the Russian Federation can quite logically be supplemented by the provision that the grounds for suspension of criminal proceedings that are connected with the absence of the accused in the process for objective reasons are not applicable provided that the defendant has filed a corresponding request for a preliminary hearing in his absence. In this case, the proceedings at this stage also, in our opinion, should be continued, and not suspended.

In the light of the new rules of the code of criminal procedure, it seems unjustified from a practical point of view to mention by the legislative bodies of a serious disease as the basis for the suspension of proceedings at this stage. As mentioned above, in accordance with paragraph 3 of Part 1 of Art. 196 of the Code of Criminal Procedure of the Russian Federation, the accused's mental and physical condition, when there is doubt about his ability to independently defend his rights and legitimate interests in criminal proceedings, is necessarily certified by the conclusion of a judicial examination, the production of which is impossible at the stage of preparation for the trial.

Only for the considered stage is characterized by the basis of suspension of criminal proceedings, not related, as it was previously in the tradition of legislative bodies, with the absence of the accused in the process, namely - the direction of the court of the request to the constitutional Court of the Russian Federation or the adoption by the Constitutional Court of the Russian Federation to consider the complaint about the compliance of the law applied or to be applied in this criminal case, the Constitution of the Russian Federation.

There are different points of view on the basis of the suspension of proceedings. So, some authors believe that this reason for the suspension of the proceedings should be preserved in the form in which it exists in the current Code of Criminal Procedure and it is not necessary to include it in the preliminary investigation stage (Popov, 2004). Others, on the contrary, justifiably believe that the suspension of criminal proceedings in connection with a court decision to appeal to the Constitutional 
Court of the Russian Federation or the adoption by the Constitutional Court of the Russian Federation of a complaint regarding the compliance of the law applied or to be applied in this criminal case with the Constitution of the Russian Federation is an independent basis for the suspension of criminal proceedings at any stage of criminal proceedings (Kochetova, 2006; Pavlik et al., 2012). It seems that a citizen has the right to file a complaint with the Constitutional Court of the Russian Federation at any stage of criminal proceedings. In connection with the foregoing, it seems possible and necessary to extend this basis for the suspension of criminal proceedings to other stages of the criminal process, where the institution of suspension of criminal proceedings is provided.

The system of circumstances that are the basis for the suspension at the trial stage, according to the Code of Criminal Procedure of the Russian Federation, includes the following situations: a) the accused disappeared; b) the presence of a mental disorder or other serious illness of the accused, excluding the possibility of his appearance. In accordance with Part 4 of the Article 247 of the Code of Criminal Procedure of the Russian Federation, a trial may be allowed in the absence of the defendant if, in a criminal case of a crime of small and medium gravity, the defendant seeks to consider this criminal case in his absence, which, of course, must be taken into account when deciding on the necessity and possibility of suspending the trial proceedings due to the disease of the defendant. The legislature has rightly distinguished between mental illness and other serious illness. It seems that the same context of this foundation should be laid down in the previous stages considered, since The need has long been ripe for developing a unified approach to the criteria of the disease, which entails the suspension of proceedings, regardless of the stage of criminal proceedings.

At the same time, it seems unreasonable that the legislative bodies did not provide at the trial stage as a basis for the suspension of proceedings in the case when the location of the accused is known, but there is no real possibility of his participation in the trial, since such situations are possible at this stage of criminal proceedings.

\section{Summary}

As a result of our study, we conclude that the system of grounds for suspending criminal proceedings established in generally corresponds to modern legal realities.

The system of grounds for suspension of proceedings in a criminal case in the legislation of Russia includes two subsystems - grounds for suspension of proceedings at the preliminary investigation stage and grounds for suspension of proceedings at judicial stages.

At the stage of preliminary investigation, the legislative bodies found quite reasonable solutions to a number of procedural problems caused by the implementation of the institution of suspension of criminal proceedings.

It seems logical that the decision of the legislative bodies to extend the action of the analyzed procedural institution not only to the accused, but also to the suspect. At the same time, certain procedural rules of this institution do not look quite convincing. For example, the introduction of such a reason for suspension as the absence of a real possibility for a suspect or accused to participate in a criminal case, when their whereabouts are known, creates uncertainty for the law enforcer, because the legislator did not explain exactly what situations can be considered as such. At the same time, the problem of developing and legislatively fixing clear criteria for the disease, which should determine the decision to suspend criminal proceedings, remains relevant.

The subsystem of grounds for suspending criminal proceedings in the judicial stages of the process, in turn, can be divided into grounds for suspending the proceedings in preparation for the trial and grounds for suspension at the trial stage.

Analyzing the grounds for suspension of the criminal case at the stage of preparation for the trial, one should proceed from the logic of the legislator, which provided for the possibility of holding a preliminary hearing in the absence of the accused at his request. In this regard, it seems necessary to supplement Art. 238 of the Code of Criminal Procedure of the Russian Federation can quite logically be supplemented by the provision that the grounds for suspension of criminal proceedings that are connected with the absence of the accused in the process for objective reasons are not applicable provided that the defendant has filed a corresponding request for a preliminary hearing in his absence. Accordingly, production in this situation should be continued, and not suspended. 
Our analysis of the system of grounds for suspension of proceedings in a criminal case allows us to substantiate the proposal on the need to disseminate such grounds for suspension of proceedings in a criminal case as sending a request to the Constitutional Court of the Russian Federation or acceptance by the Constitutional Court of the Russian Federation for consideration of a complaint about the conformity of the law applied or to be applied in this criminal case, the Constitution of the Russian Federation and at other stages of the criminal process in which the institution of suspension of proceedings is applied wa in a criminal case.

The legislative bodies, quite rightly, in formulating the grounds for the suspension of the criminal case in relation to the stage of the trial, distinguished between mental disorder and other serious illness. It is advisable to develop a unified approach to the criteria for illness, both mental and other serious, entailing precisely the suspension of criminal proceedings, regardless of the stage of criminal proceedings in which the relevant decision is made.

\section{Conclusion}

Thus, the current legislation has significantly changed approaches to the legal regulation of the institution of suspension of proceedings in a criminal case as a whole and, in particular, the grounds for suspension of proceedings in a criminal case, expanding their list and filling a number of them with new content, which, of course, requires further study and reflection. At the same time, there is a potential for further improvement of the legislation with respect to the system of grounds for suspending criminal proceedings. The realization of this potential will, on the one hand, increase the level of protection of the legal rights and interests of participants in criminal proceedings, and, on the other hand, reduce the likelihood of artificially delaying criminal proceedings.

\section{Acknowledgements}

The work is performed according to the Russian Government Program of Competitive Growth of Kazan Federal University.

\section{References}

Choo, A. L. T. (2008). Abuse of Process and Judicial Stays of Criminal Proceedings (pp. 71-96). Oxford: Oxford University Press.

Forensic statistics for 2018. Official site of the Judicial Department at the Supreme Court of the Russian Federation. URL: http://www.cdep.ru/index.php?id=79\&item=4891 (accessed: 06/05/2019).

Harris, J. (2005). Stays of Proceedings and the Brussels Convention. International \& Comparative Law Quarterly, 54(4), 933-950.

Ibragimova, L. D. (2012). The procedural form of suspension of proceedings in the course of and following the results of the preliminary hearings. Siberian Law Journal, 1(56), 114-118.

Klyukova, M. E. (1990). Suspension of a Case in the Soviet Criminal Trial: Autoref. dis. ... cand. legal sciences. Kazan,. 22 pages.

Kochetova, A. V. (2006). Actual Issues of the Institution of Suspension of Criminal Proceedings: Autoref. dis. ... cand. legal sciences. Chelyabinsk, $28 \mathrm{p}$.

McDermott, H. (2016). Seeking a Stay of Proceedings for Irregular Apprehension before International Courts: Fighting a Losing Battle against the Pursuit of International Criminal Justice. Journal of International Criminal Justice, 14(1), 145-169.

McLachlan, J. (1990). Forum Non Conveniens and Stays of Proceedings in Australia. The Cambridge Law Journal, 49(1), 37-39.

Pavlik, M. Yu., Solodovnik, V. V., Roganov, S. A., \& Nikolaeva, T. G. (2012). Features of legal regulation of the grounds for suspension of the preliminary investigation. Bulletin of St. Petersburg University of the Ministry of Internal Affairs of Russia, 2(54), 108-114.

Popov, A. M. (2004). Problems of Improving the Grounds and Conditions for the Suspension of the Preliminary Investigation: Autoref. dis. ... cand. legal sciences. Saratov, 26 pages.

Roach, K. (1997). The Evolving Test for Stays of Proceedings. Crim. LQ, 40, 400-443..

Spencer, J. R. (2014). International Law, People Trafficking and the Power to Stay Criminal Proceedings for Abuse of Process. The Cambridge Law Journal, 73(1), 11-14. 